\title{
Özel Çeşitli Kurslar Denetim Rehberinin Yasal Belgeler ve Alanyazın Açısından incelenmesi
}

\author{
Dr. Özden Ölmez Ceylan \\ MEB-Türkiye \\ olmezozden@gmail.com
}

\author{
Hüseyin Yaldız \\ MEB-Türkiye \\ huseyinyaldiz@gmail.com
}

\begin{abstract}
Özet:
Bu araştırmanın amacı Milli Eğitim Bakanlığı Teftiş Kurulu Başkanlığı tarafından yayımlanan Özel Çeşitli Kurslar Rehberlik ve Denetim Rehberi'ni yasal belgeler ve alanyazın temelinde incelemek ve öneriler geliştirmektir. Rehber nitel araştırma yöntemine göre doküman analizine tabi tutulmuştur. Veriler içerik analizi ile incelenmiştir. Analiz sonucunda rehberin yasal belgelerle genel olarak tutarlı olduğu sonucuna ulaşılmıştır. Ancak analiz doğrultusunda gönderme yapılan maddelere göre içerik eksikliği, yasal belgelere göre güncel olmama, yasal dayanağa göre fazla ve hatalı ifadelendirme sonuçlarına ulaşılmıştır. Rehberin alanyazınla ilişkisi ele alındığında ise genel olarak tutarlığa sahip olsa da alanyazınla tutarsız kullanılan kavramların olduğu, bilimsel çalışmalara atıf yapılmadığı, bazı kavramların kullanılmamasının içerik eksikliğine neden olduğu ve alanyazına aykırı kullanımların yer aldığı sonuçlarına ulaşılmıştır. Bu bağlamda müfettişlere rehberin hazırlanmasına yönelik seminerler verilmesi, rehberin güncel tutulması için rehbere çevirim içi linkler eklenmesi ve güncel tutulması için yazılım oluşturulması, alanyazındaki araştırma sonuçlarının rehbere eklenmesi getirilen önerilerden bazılarıdır.
\end{abstract}

Keywords: Eğitim denetimi, denetim rehberi, özel ve çeşitli kurslar

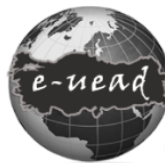

E-Uluslararası Eğitim Araştırmaları Dergisi, Cilt: 12, Sayl: 1, 2021, ss. 53-67

DOI: 10.19160/ijer.831880

\section{Önerilen Atıf}

Ölmez Ceylan, Ö. \&. Yaldız, H. (2021). Özel Çeşitli Kurslar Denetim Rehberinin Yasal Belgeler ve Alanyazın Açısından Incelenmesi, E-Uluslararası Eğitim Araştırmaları Dergisi, Cilt: 12, Sayı: 1, 2021, ss. 53-67, DOI: 10.19160/ijer.831880 


\section{Giriş}

Eğitim sistemleri birçok bileşenden oluşan kompleks bir yapıya sahiptir. Birey, eğitim hayatını sadece okullarda sürdürmez, aynı zamanda çeşitli kurslarla sosyal ya da kültürel faaliyetlerde bulunur. Bu tür kurslar eğitim sisteminin temel amaçlarını desteklemek amacıyla çeşitli alanlarda hizmet vermektedir. Bu çeşitlilik spor, sanat, yabancı dil alanlarını kapsadığı gibi matematik, fen bilimleri gibi bazı akademik alanları da bünyesinde barındırır. Bu noktada bu kursların niteliği de üzerinde durulması gereken bir nokta olarak öne çıkar. Her yaş grubuna hitap eden ve farklı alanlarda hizmet veren bu kursların Milli Eğitim Bakanlığının temel amaç ve ilkeleri çerçevesinde hizmet vermesi, bireyin gelişimine katkı sunması beklenmektedir. Bu noktada kursların farklı açılardan toplumu etkilemesi denetimini de gerekli kılmaktadır.

Denetim mekanizması, kurumların niteliğinin artırıması ve toplumun gelişimine katkı sunması açısından önem taşımaktadır. Diğer bir deyişle denetim, bir kurumun nitelik ve niceliği açısından belirlenen hedeflere uygun bir gelişim göstermesini destekleyen bir mekanizmadır. Bu nedenle denetim, sorunlu alanlar için gerekli tedbirlerin alınması ve verimliliğin artırıması noktasında yaşamsal bir önem taşır (Taymaz, 2015). Örgütlerin hedeflerini ne ölçüde gerçekleştirebildiklerinin anlaşılması ve verimliliği girdi, işleme süreci ve çıtıların planlı ve sürekli bir biçimde değerlendirilmesiyle sağlanabilir (Aydın, 2014). Bu sürecin sağlıklı bir şekilde yürütülmesi de denetimin toplumsal faydaya dönüşme sürecindeki rolünü açıklamaktadır. Nitekim Bursalıoğlu (2010) denetimi, örgütsel davranışı kamu yararı adına kontrol etme yöntemi olarak tanımlamaktadır.

Denetimin amacı ise olması gereken standartların belirlenip var olan durumla arasındaki uygunluğun ortaya konulması olarak ifade edilebilir (Toprakçı ve Taş, 2020). Denetimin bu amaç doğrultusunda etkili bir şekilde yapılabilmesi de önem taşımaktadır. Etkili bir denetim için denetici yeterlilikleri kadar denetim için kullanılan araçların da niteliği üzerinde durulması denetim alanının geliştirilmesi açısında gerekli olduğu söylenebilir. Bürokrasi kuramında kurallar sistemi ilkesi ile yazılı kuralların varlığının görevsel davranışı sağladığı vurgulanmaktadır. Aynı zamanda Weber'in bu kuramda ortaya koyduğu ilkeler arasında yer alan işlemler sistemi ile de somut ilkelerle belirlenen işlerin nasıl yapılacağının da ayrıntılı bir şekilde yazılı hale getirilmesi gerekliliği üzerinde durulur (Bülbül, 2018). Bu noktada denetimin amacına uygun gerçekleştirilebilmesi için görev ve sorumlulukların kimlere ait olduğu ve bu görevlerin nasıl yapılacağının nesnel bir şekilde yazılı hale getirilmesi gerektiği anlaşılmaktadır. Bu bağlamda Milli Eğitim Bakanlığı (MEB) teşkilatlanmasında yer alan Teftiş Kurulu Başkanlığı "merkez, taşra, yurt dışı teşkilatında yapılan her türlü faaliyetin; mevzuata, plan ve programa uygunluğunu sağlama ve eğitim-öğretim sistemine değer katmak amacıla rehberlik, denetim, inceleme, ön inceleme ve soruşturma işlemlerini" yürütmekle görevlendirilmiştir (Teftiş Kurulu Başkanlığı, 2020). Teftiş Kurulu Başkanlığı eğitim ve öğretimde mükemmelliğin yakalanması ve uluslararası standartların sağlanması için rehberlik ve denetim sorumluluğunu üstlenmiştir ve maarif müfettişleri 20.08.2017 tarih ve 30160 sayılı MEB Teftiş Kurulu Yönetmeliği uyarınca bu sorumluluğu yerine getirmektedir (MEB, 2017).

Maarif müfettişlerinin görev ve sorumluluklarında uygulama birliğinin sağlanması ve görevlerinin belirli bir standarda göre yapılması için Teftiş Kurulu Başkanlığı tarafından rehberlik ve denetim rehberleri hazırlanmıştır (MEB, 2014). Eğitim denetiminin etik tartışmaları arasında yer alan değerlendirmenin nesnel gözlem ve verilere dayandırılması ve değerlendirme ölçütlerinin somut olması ve taraflarca bilinmesi (Aydın, 2003) gibi açılardan denetim rehberleri de işlevselliği sağlandığında denetimin niteliğini artırıı bir rol oynayabilir. 652 sayılı Milli Eğitim Bakanlığının Teşkilat ve Görevleri Hakkında Kanun Hükmünde Kararnamede 6528 sayılı Kanun ile 14.03.2014 tarihinde yapılan değişiklik ve 24.05.2014 tarihindeki Resmi Gazete'de yayımlanarak yürürlüğe giren MEB Rehberlik ve Denetim Başkanlığı ile Maarif Müfettişleri Başkanlıkları Yönetmeliği'nin 70. maddesinde müfettişlerin denetim faaliyetlerinde denetim rehberlerinden yararlanmasına ilişkin açıklamalar yer almaktadır. Sözü edilen denetim rehberleri temel eğitim kurumları, il/ilçe milli eğitim müdürlükleri, özel eğitim kurumları gibi MEB'e bağlı her bir kuruma 
özel olarak hazırlanmıştır. Bu araştırmada denetim rehberleri arasında yer alan Özel Çeşitli Kurslar Rehberlik ve Denetim Rehberi ele alınmıştır.

Özel Çeşitli Kurslar Rehberlik ve Denetim Rehberi MEB'e bağlı özel çeşitli kursları kapsamaktadır ancak rehberde bu kursların neler olduğu açıklanmamıştır. Rehberin giriş kısmında diğer rehberlerde olduğu gibi amaç, kapsam, dayanak ve tanımlara yer verilmiştir. Ardından denetim ilkeleri, denetim esasları, denetim sürecinin planlanma ve yürütülme aşamaları, raporlama standartları yer almaktadır. Rehberlik ve denetim raporlama standartları her bir rehberin denetim yapacağı kurumun özelliklerine göre şekillendirilmiştir. Özel Çeşitli Kurslar Rehberi'nde kurumlarım eğitim-öğretim faaliyetleri, yönetim faaliyetleri, mali iş ve işlemler, izleme ve değerlendirme, yönetici bilgileri, örnek uygulamalar ve genel değerlendirme aşamaları yer almaktadır. Bu bölümlerde ilgili kurumlara özgü denetim unsurları ve açıklamalarına yer verilmiştir. Maddelerde, açıklamaların ilişkili olduğu yasal belgelere atıflar yapılmıştır. Bu noktada rehberdeki maddelerle ilişkilendirilen yasal belgelerin denetimi yapacak kişiyi doğru, ayrıntılı ve güncel bir şekilde yönlendirilmesi beklentisi oluşmaktadır. Tersi bir durum karmaşaya yol açarak denetim rehberinin ortaya çıkış amacına ulaşamamasına ve bu rehberin kullanıcı dostu olmamasına neden olabilir. Bu duruma ilişkin mevzuatların dağınık olması, sık değiştiği için günceli takip etmede zorlanılması (Özmen ve Şahin, 2010) gibi sorunlar alanyazında, müfettişlerin görevlerini getirirken karşılaştıkları sorunlar arasında da dile getirilmiştir.

Eğitim kurumlarının işleyişinin hukuki esaslara dayandığı (Toprakçı, Beytekin ve Doğan, 2018) düşünüldüğünde rehberin gönderme yapılan yasal belgelerle tutarlılığı da önem kazanmaktadır. Yasal belgelerle tutarlı olmasının yanı sıra rehberlerin bilimsel bir temele dayandırılmasının da niteliği açısından önem taşıdığı düşünülmektedir. Hoy ve Miskel (1978) eğitim denetiminin daha bilimsel bir altyapı kazanması için verilecek kararların ve uygulamaların bilgiye dayanması gerektiğini vurgulamaktadır. Toprakçı vd. (2010) ise eğitim pratiği, teoriye dayandırıldığında ve teori ile pratik sentezlenerek yasal belgelere yansıtıldığında eğitim bilimliliğinden söz edilebileceğini vurgulamıştır. Bursalığlu (1979) da kuramlara dayandırıldığında denetimsel davranışın yönetici ve deneticilere yol gösterici olacağından söz eder. Bilimsel çalışmaların denetim alanında bir ihtiyaç olduğu, özellikle de etkili ve sistemdeki sorunlara odaklanmış teorik alt yapısı sağlam araştırmaların denetim alanında niteliği artıracağı bazı araştırmalarda (Bozak, Seraslan ve Çakır, 2017; Konan, Bozanoğlu, Çetin, 2019) dile getirilmiştir. Alanyazında yer alan kabul görmüş araştırmaların sonuç ve önerilerinin denetim sürecinde karşılaşılabilecek sorunlara çözüm bulma noktasında yol gösterici ve kolaylaştırıcı olacağı söylenebilir. Bu noktada rehberlerin alanyazınla ilişkilendirilmesi de rehberin taşıması gereken özellikler arasında düşünülebilir. Ancak özel çeşitli kursların niteliği ve denetiminin ele alındığı herhangi bir araştırmaya rastlanmamıştır. Bu noktada araştırmacıların da denetim alanına özgü araştırma çeşitliliği sağlamasının bir ihtiyaç olduğu söylenebilir. Rehberin resmi belge olması nedeniyle alanyazın desteğini daha çok denetim anlayışı ve ilkelerin alanyazın tutarlılığı bağlamında ele alınması düşünülebilir. Bu araştırmada Özel Çeşitli Kurslar Rehberlik ve Denetim Rehberi'nin yasal belgeler ve alanyazın temelinde incelenmesi amaçlanmıştır. Bu bağlamda araştırmanın denetim alanyazınına katkı sunacağı, araştırmada belirlenen olumlu ve olumsuz noktalarla daha sonra yapılacak uygulama ve araştırmalara ışık tutacağı beklenmektedir.

\section{YÖNTEM}

\section{Araştırma modeli:}

Araştırmada, Özel Çeşitli Kurslar Rehberlik ve Denetim Rehberi'nin incelenerek değerlendirilmesi ve öneriler getirilmesi amaçlanmış bu bağlamda nitel araştırma yöntemi kullanılmıştır. Nitel araştırma gözlem, görüşme, doküman analizi gibi yöntemlerle durumların bütüncül bir şekilde ortaya konulmasını sağlamaktadır (Yıldırım ve Şimşek, 2013). Doküman incelemesi kişisel dokümanlarda kullanıldığı gibi kamu ve arşiv dokümanlarında da kullanılabilir. Kamu dokümanları, kurumların olay ya da süreçlerin göstergesi olarak düşünülebilir. Bu nedenle 
eğitimdeki değişimlerin ve süreçlerin ortaya konulması açısından değerli kaynaklar olduğu söylenebilir. Rehberlik ve denetim rehberleri de MEB Teftiş Kurulu Başkanlığının denetimde uygulama birliği ve standartlaşmayı sağlamak amacıyla kullandığı kamu belgeleri olarak doküman incelemesine uygun kaynaklar olarak görülmüş ve doküman incelemesinin aşamalarına göre analiz edilmiştir.

\section{Çalışma Dokümanı:}

MEB Teftiş Kurulu Başkanlığı, 2016 yılında çeşitli kurumların teftişine yönelik olarak hazırlanan 16 adet rehberlik ve denetim rehberi yayımlamıştır. Bu rehberler maarif müfettişlerinin teftiş sürecinde uygulayacakları esasları içermektedir. Çalışma dokümanı yayımlanan rehberler arasında yer alan Özel Çeşitli Kurslar Rehberlik ve Denetim Rehberi'dir. Rehbere, MEB Teftiş Kurulu Başkanlığı'nın internet sitesinin (tkb.meb.gov.tr) "Yayımlarımız" sayfasından 24.04.2020 tarihinde ulaşılmıştır. Yasal belgelere ve alanyazına çevirim içi ortam ile araştırmacının sanal ve gerçek kütüphanesinde bulunan kaynaklardan ulaşılmıştır.

\section{Verilerin Toplanması ve Analizi:}

Doküman inceleme süreci; belgeye ulaşma, orijinalliğin kontrolü, belgenin anlaşılması, analiz ve verinin kullanılması aşamalarından oluşmaktadır (Yıldııım ve Şimşek, 2013). Bu aşamalar doğrultusunda Özel Çeşitli Kurslar Rehberlik ve Denetim Rehberi içerik analizine tabi tutulmuştur. İçerik analizi, veriler arasındaki ilişkinin ortaya çıkarılması ve verilerin açıklanabilmesi amacıyla kullanılır. İçerik analizinde temelde yapılan işlem, birbirine benzeyen verileri belirli kavramlar ve temalar çerçevesinde bir araya getirmek ve bunları okuyucunun anlayabileceği bir biçimde düzenleyerek yorumlamaktır. Bu analizde verilerin mutlaka nicelleştirilmesi gerekmeyebilir ancak veriler yüzde dağılımı ya da sayısallaştırma yoluyla da verilebilir (Yıldırım ve Şimşek, 2013). Bu bağlamda denetim rehberi incelenerek belgenin anlaşılması süreci gerçekleştirildikten sonra içerik analizi ile temalar oluşturulmuş ve tablolarda sayısallaştırmadan yararlanılmıştır. Illk tema olarak denetim rehberinin yasal belgelerle ilişkisi ele alınmıştır. Bu temada rehberdeki açıklamalar ile belirtilen kanun, yönetmelik, yönerge, genelge ve diğer belgelerin tutarlı olup olmadığı üzerinde durulmuştur. Illgili mevzuatı oluşturan belgelere MEB'in internet sitesinden ulaşılarak detaylı incelemeler yapılmıştır. Denetim rehberinin alanyazın belgeleri ile ilişkisi ikinci tema olarak belirlenmiş ve rehberin alanyazınla tutarlı olup olmadığına bakılmıştır. Analiz sürecinde çevrim içi ortam, gerçek ve sanal kütüphaneler ile alanyazınsal zihin çerçeveleri (alanyazında ustalık) temel alınmıştır. Alanyazında ustalık kavramı, bilim insanı yeterliğine ve alana özgü uzmanlığa sahip olma durumunu karşılamaktadır. Araştırmacıların zihin çerçevelerinin sınırılığını genişletmek amacıyla aşkınlık seviyesine gelinceye kadar alanyazına ilişkin okumalar yapılmış ve bu okumalar sonucunda belirlenen temalar, kategoriler ve kodlara ulaşılmıştır. Veriyi kullanma aşamasında temaya yönelik alıntılar ve yorumlar eklenerek ayrıntılı raporlandırma yapılmıştır. Tüm maddeler bu yöntemle incelenerek tablolar oluşturulmuş ve alıntılarla raporlaştııılmışıı. Analiz sürecinde bazı maddelerin birden fazla alt temayla ilişkili olduğu görülmüştür. Bu durum göz önünde tutularak ilgili madde sayısallaştırma yapılırken ilişkili olduğu her alt temada yeniden kullanılmıştır. Tablo 1'de örnek bir inceleme yer almaktadır.

\section{Geçerlik ve Güvenirlik}

Nitel araştırmalarda geçerlik ve güvenirliğin sağlanabilmesi için bazı önlemler alınmaktadır. Bunun için uzman görüşü ve meslektaş teyidi gibi çeşitli stratejiler kullanılmaktadır. Meslektaş teyidi elde edilen verilerin karşılaştııılarak uyuşumun ortaya konmasına yönelikken uzman incelemesi, araştırma sürecine eleştirel gözle bakan ve araştırmacıya geribildirimde bulunan uzman görüşünü ifade etmektedir (Creswell, 2003; Yıldırım ve Simşek, 2013). Araştırmanın geçerliğinin sağlanması için öncelikle meslektaş teyidine gidilmiştir. Bu amaçla MEB Teftiş Kurulu Başkanlığı'nın farklı kurumlara yönelik rehberlik ve denetim rehberlerini inceleyen araştırmacılar düzenli aralıklarla bir araya gelmiştir. İnternet ortamında her hafta belirlenen gün ve saatte canlı toplantı araçları üzerinden 
Tablo 1. Özel Çeşitli Kurslar Rehberlik ve Denetim Rehberi'nin içerik analizine ilişkin temalara göre örnek incelemeler

\begin{tabular}{|c|c|c|c|}
\hline $\begin{array}{l}\text { Te } \\
\text { ma }\end{array}$ & $\begin{array}{c}\text { Katego } \\
\text { ri } \\
\end{array}$ & $\begin{array}{c}\text { Kodl } \\
\text { ar }\end{array}$ & Temayla ilişkilendirilen ifadeler ve yasal belgedeki ilgili madde \\
\hline \multirow{6}{*}{ 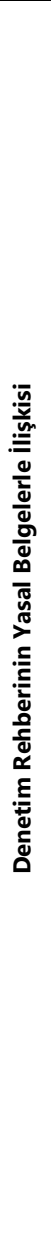 } & \multirow[t]{3}{*}{ 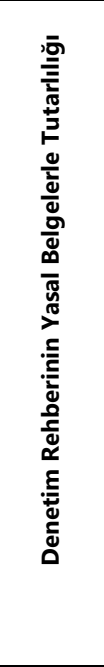 } & \multirow[t]{3}{*}{ 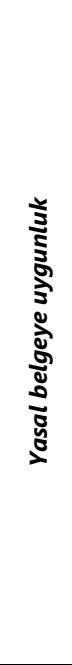 } & $\begin{array}{l}\text { Rehberdeki ifade: } \\
\text { 2. EĞiTiM-ÖĞRETiM FAALIYETLERI } \\
\text { 2.2.Eğitim-Öğretim Ortamları } \\
\text { 7. Kurumun bulunduğu binada; meyhane, kahvehane, kıraathane, bar, elektronik oyun merkezleri gibi } \\
\text { umuma açı yerler ile açık alkollü içki satılan yerlerin bulunmaması. } \\
\text { Yasal belgedeki karşılığı: } \\
\text { Özel Öğretim Kurumları Kanunu Md.4 } \\
\text { Kurucu/kurucu temsilcisinin nitelikleri ve kurum binaları } \\
\text { MADDE } 4 \\
\text {...Meyhane, kahvehane, kıraathane, bar, elektronik oyun merkezleri gibi umuma açı yerler ile açı alkollü } \\
\text { içki satılan yerlerin, okul binalarından kapıdan kapıya en az yüz metre uzaklıkta bulunması zorunludur. Özel } \\
\text { eğitime muhtaç bireylerin devam ettikleri öğretim kurumları ile okullar dışındaki diğer özel öğretim } \\
\text { kurumlarında bu zorunluluk aranmaz. Ancak, söz konusu özel öğretim kurumlarıyla yukarıda belirtilen } \\
\text { türdeki iş yerleri aynı binada bulunamaz... }\end{array}$ \\
\hline & & & ilişkilendirme \\
\hline & & & $\begin{array}{l}\text { Rehberdeki maddede Özel Öğretim Kurumları Kanunu Madde 4'e gönderme yapılmıştır. İlgili madde, } \\
\text { MEB'in internet sayfasından Özel Öğretim Kurumları Kanunu'na ulaşılarak incelenmiş ve rehberdeki } \\
\text { açıklamayla karşılaştırılmıştır. Maddenin içeriğinin yasal belge ile uyumlu olduğu saptanmıştır. Bu nedenle } \\
\text { bu madde yasal belgeye uygunluk kodu ve denetim rehberinin yasal belgelerle tutarlılığı alt temasıyla } \\
\text { ilişkilendirilmiştir. }\end{array}$ \\
\hline & \multirow{3}{*}{ 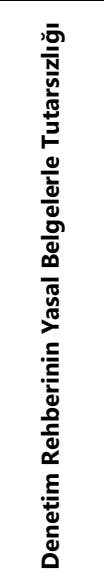 } & \multirow{3}{*}{ 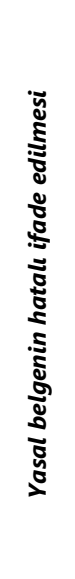 } & $\begin{array}{l}\text { Rehberdeki ifade: } \\
\text { 2. EĞiTiM-ÖĞRETIM FAALIYETLERI } \\
\text { 2.2.Eğitim-Öğretim Ortamları } \\
\text { 3. Sınıf ve grupların oluşturulması (Özel Öğretim Kurumları Yönetmeliği Md.5/f) } \\
\text { Yasal belgedeki karşılığı: } \\
\text { MiLLî EĞiTiM BAKANLIĞı ÖZEL ÖĞRETIM KURUMLARI YÖNETMELIĞi } \\
\text { Kurum açma } \\
\text { MADDE 5 } \\
\text { f) Çeşitli kurslar, Özel eğitim ve rehabilitasyon merkezleri, motorlu taşıt sürücüleri kursları ve hizmet içi } \\
\text { eğitim merkezlerinin uygulayacakları öğretim programının onaylandığı Talim ve Terbiye Kurulu kararının } \\
\text { tarih ve sayısı. (Ek cümle:RG-8/8/2015-29439) }\end{array}$ \\
\hline & & & ilişkilendirme \\
\hline & & & $\begin{array}{l}\text { Rehberdeki maddede Özel Öğretim Kurumları Yönetmeliği Madde } 5(f)^{\prime} \text { e gönderme yapılmıştır. İlgili madde, } \\
\text { MEB'in internet sayfasından Özel Öğretim Kurumları Yönetmeliği'ne ulaşılarak incelenmiş ve rehberdeki } \\
\text { açıklamayla karşılaştırılmıştır. Maddenin içeriği sınıf ve grupların oluşturulmasıyla ilgiliyken gönderme } \\
\text { yapılan maddenin uygulanan öğretim programlarına yönelik olduğu saptanmıştır. Bu nedenle bu madde } \\
\text { yasal belgenin hatalı ifade edilmesine yönelik kod ve alt temayla ilişkilendirilmiştir. }\end{array}$ \\
\hline \multirow{3}{*}{ 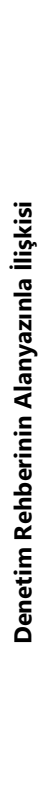 } & \multirow{2}{*}{ 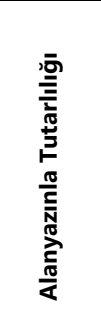 } & \multirow{2}{*}{ 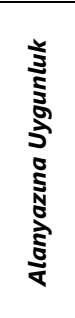 } & $\begin{array}{l}\text { Rehberdeki ifade: } \\
\text { Bulguların Elde Edilmesi ve Önerilerin Geliştirilmesi } \\
\text { "Denetim grubu bu aşamada, kendi içinde yaptığı görev paylaşımı doğrultusunda, denetim sürecinde } \\
\text { bulgulara ulaşma yoluna gider. Denetim sonucunda elde ettiği bulguları değerlendirerek, kurum yönetimi } \\
\text { ve çalışanlarına katkı sağlayarak, kurumun performansını artıracak öneriler geliştirir. } \\
\text { lişkilendirme }\end{array}$ \\
\hline & & & $\begin{array}{l}\text { Rehberde denetim sürecinde bulguların değerlendirildikten sonra öneriler geliştirilerek performansının } \\
\text { artırılması amacıyla kurumla paylaşılması sürecinden söz edilmiştir. Bu anlayış çağdaş denetimde önemli bir } \\
\text { yere sahiptir bu nedenle bulgu uygunluk kodu içerisinde değerlendirilmiştir. }\end{array}$ \\
\hline & 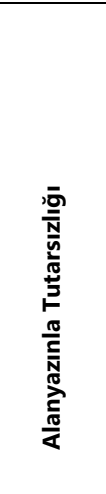 & 离 & $\begin{array}{l}\text { e) İşbirliği ve katıımı öngörmek, } \\
\text { f) Başarıyı öne çıkarmak, özendirmek, teşvik etmek ve } \\
\text { ödüllendirmek, } \\
\text { g) Personelin mesleki yeterliğini geliştirmek, } \\
\text { ğ) Objektif olmak, } \\
\text { h) Gelecek yönelimli olmak, } \\
\text { l) Etkililik, ekonomiklik ve verimlilik esaslarını dikkate almak, } \\
\text { i) Millî birlik ve bütünlüğümüzün temel unsurlarından biri } \\
\text { olan Türkçenin doğru kullanılması hususunda gerekli } \\
\text { duyarlılığı göstermek, } \\
\text { j) Kurumlarda rehberlik ve denetim faaliyetlerini birlikte } \\
\text { yürütmek. }\end{array}$ \\
\hline
\end{tabular}

ilişkilendirme

Rehberde denetim ilkeleri arasında "hesapverebilirlik" ilkesi yer almamaktadır. Alanyazında denetim ilkeleri arasında bu kavram yer almakta ve etkili denetim için gerekli görülmektedir. Bu nedenle ilkeler arasında "hesapverebilirlik" kavramının yer almaması içerik eksikliği kodu ile ilşkilendirilmiştir. 
toplantılar düzenlenmiş ve tekrar izlenebilmesi için bu toplantılar kaydedilmiştir. Toplantılarda öncelikle rehberlerin hangi yönlerden incelenebileceğine ilişkin tartışmalar gerçekleştirilmiştir. Ardından araştırmacılar inceleyecekleri rehberlere yönelik içerik analizi yaparak temaları ve alt temaları oluşturmuştur. Oluşturulan temalar ve alt temalar karşılaştırılarak benzer ve farklı yönler üzerinde durulmuştur. Anlaşmazlığa düşülen noktalar tartışılmış ve fikir birliğine ulaşılıncaya dek toplantılar sürdürülmüştür. Bu toplantılarda uzman görüşü alınması amacıyla denetim alanında yayınları olan alanında yetkin bir akademisyen ile bir maarif müfettişi de yer almıştır. Bu uzmanlar toplantı sürecinde geribildirimlerde bulunmuşlardır. Örneğin denetim ilkeleri üzerine yapılan toplantıda araştırmacıların bir kısmı rehberde belirtilen ilkelerin uygun olduğu görüşünü ileri sürmüşlerdir. Ancak bir kısmı fazla ifadelendirmenin olduğu yönünde görüş bildirmişlerdir. Süreçte alanyazın taraması yapılarak ve uzman görüşleri doğrultusunda rehberdeki ilkelerde fazla ifadelendirmenin olduğu sonucuna ulaşılmış ve fikir birliği ile çalışmada analiz sonucuna bu yönde yansıtılmıştır. Geçerlik ve güvenirliğin sağlanması için değerlendirilen rehberlerin görüş birliğine dayalı olarak analiz edilmesine ve ayrıntılı raporlaştırılmasına dikkat edilmiştir. Ayrıca dış güvenirliği artırmak amacıyla talep edilmesi durumunda paylaşılması ya da başka bir araştırmada karşılaştırma yapılabilmesi için araştırmanın ham verileri saklanmıştır.

Birlikte hareket edilerek şekilenen rehberlerle ilgili çalışmaların bazıları yayımlanmıştır (Toprakçı ve Bakır 2020; Tonbul ve Ata 2020; Özdemir ve Altuntaş 2020; Akçay Güngör 2020; Kahraman 2020; Tonbul ve Keleş 2020; Ölmez ve Algam 2020; Toprakçı ve Özerten 2020). Bu çalışma hakem süreci ve yazım ile ilgili iş ve işlemlerin uzamasından dolayı sonra yayımlandığından onlara vurgu yapmak gereği duyulmuştur.

\section{BULGULAR VE YORUM}

Bu bölümde bulgular, çalışmanın amacına uygun olarak "Özel Çeşitli Kurslar Rehberlik ve Denetim Rehberi'nin Yasal Belgelerle İlişkisi" ve "Özel Çeşitli Kurslar Rehberlik ve Denetim Rehberi'nin Alanyazınla İlişkisi" başlıkları altında verilmiştir. Analiz sonucunda ortaya çıkan temalar, kategoriler, kodların dağılımı ve bulguları oluşturan alıntılar aşağıda yer almaktadır.

\section{1. Özel Çeşitli Kurslar Rehberlik ve Denetim Rehberi'nin Yasal Belgelerle illişkisi}

Araştırmanın bu başlığı altında denetim rehberinin yasal belgelerle ilişkisi incelenmiştir. Bu bağlamda denetim rehberinin yasal belgelerle tutarlılığ ve tutarsızlığı alt temaları oluşturulmuştur. Tutarlılı teması altında yasal belgeye uygunluk alt teması yer almaktadır. Tutarsızlık alt teması altında içerik analizi sonucunda yasal belgenin hatalı ifade edilmesi, yasal belgeye göre güncel olmama, eksik ifade edilme, fazla ifadelendirme, ilgili yasal dayanaklara eksik gönderme kodlarına yer verilmiştir. Analiz sonucunda ulaşılan tama, kategori, kodlar ve frekanslar Tablo 2'de gösterilmektedir.

Tablo 2. Özel Çeşitli Kurslar Rehberlik ve Denetim Rehberi'nin yasal belgelerle ilișkisinin incelenmesi

\begin{tabular}{|c|c|c|c|}
\hline Tema & Kategoriler & Kodlar & $f(n)$ \\
\hline \multirow{7}{*}{ 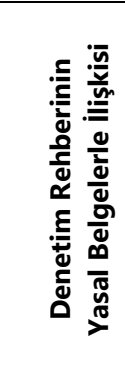 } & $\begin{array}{l}\text { Denetim Rehberinin Yasal } \\
\text { Belgelerle Tutarlılığı }\end{array}$ & Yasal belgeye uygunluk & 63 \\
\hline & \multirow{6}{*}{$\begin{array}{l}\text { Denetim Rehberinin Yasal } \\
\text { Belgelerle Tutarsızlığı }\end{array}$} & Yasal belgenin hatalı ifade edilmesi & 2 \\
\hline & & Yasal belgeye göre güncel olmama & 3 \\
\hline & & Yasal belgeye göre eksik ifade edilme & 13 \\
\hline & & Yasal belgeye göre fazla ifadelendirme & 2 \\
\hline & & İlgili yasal belgelere eksik gönderme & 26 \\
\hline & & Toplam & 109 \\
\hline
\end{tabular}




\subsection{Denetim Rehberinin Yasal Belgelerle Tutarlılığı}

Tablo 2 incelendiğinde denetim rehberinin yasal belgelerle tutarlıı̆ı kategorisi altında yasal belgeye uygunluk kodu yer almaktadır. Bu kod kapsamında rehberdeki maddelerin açıklamalarında yer alan yasal göndermelerin yasal belgelerdeki karşוlıklarının uyumuna bakılmıştır. Bu bağlamda denetim rehberindeki göndermelerin genel olarak yasal belgelere uygun ( $n=63$ ) olduğu görülmektedir. Yasal belgelere uygun olması, giriş kısmında belirtildiği üzere rehberin "kurum denetiminde uygulama birliği sağlamak ve maarif müfettişlerine denetimlerde yol göstermek" amacına uygunluğunu göstermektedir. Ancak bu durum rehberin ortaya çıkış amacına büyük ölçüde uygun olduğunu gösterse de denetim gibi hassas bir süreçte kullanıcı dostu olması beklenen rehberin tamamının yasal belgelerle tutarlı olması beklenmektedir. Bu durumun, rehberin hazırlanma sürecinin tam olarak sağlıklı yürütülmediğinin göstergesi olduğu söylenebilir.

\subsection{Denetim Rehberinin Yasal Belgelerle Tutarsızlığı}

Denetim rehberinin yasal belgelerle tutarsızlı̆̆ $(n=46)$ kategorisi incelendiğinde en çok ilgili yasal belgelere eksik gönderme $(\mathrm{n}=26)$, en az yasal belgenin hatalı ifade edilmesi $(\mathrm{n}=2)$ koduyla ilişki görülmüştür.

Yasal belgenin hatalı ifade edilmesine $(n=2)$ yönelik bulgulara rehberdeki açıklamada belirtilen numara ile gönderme yapılan belgedeki eşleştirmede hata olduğunda ulaşılmıştır. Araştırmada ele alınan rehberin Eğitim-Öğretim Etkinlikleri başlığı altında yer alan sınıf ve grupların oluşturulmasıyla ilgili maddede Özel Öğretim Kurumları Yönetmeliği Madde 5'e gönderme yapılmıştır. Ancak bu maddenin içeriği incelendiğinde özel öğretim kurumlarında uygulanan öğretim programlarına yönelik olduğu görülmüştür. Bu durum rehberi hazırlayanların sehven yaptığı bir yazım hatasından ya da güncellenmemesinden kaynaklandığı söylenebilir.

Tutarsızlık alt teması altında yasal belgeye göre güncel olmamaya $(n=3)$ ilişkin bulgular incelendiğinde 3 maddede güncelleme yapılmadığı belirlenmiştir. Örneğin özel çeşitli kurslarla ilgili yasal değişikliğin rehberde güncele uygun olmadığı görülmüştür. 14 Mart 2014 tarihinde Resmi Gazete'de yayımlanması ile resmen yürürlüğe giren dershanelerin kapatılmasına ve dönüştürülmesine ilişkin Milli Eğitim Temel Kanunu ile Bazı Kanun ve KHK'larda Değisşiklik Yapan 6528 Sayılı Kanun'un çerçevesinde denetimin yapılması gerekmektedir. Özel çeşitli kursların denetiminde yasal belgede yer alan 4 Ağustos 2017'ye kadar kurumsal dönüşümün tamamlanması şartı göz önünde bulundurulmalı ve 25.08.2017 tarihli Özel Öğretim Kursları Denetimi yazısı temel alınarak denetim gerçekleştirilmelidir. Ancak rehberde bu hususta güncel belgelere gönderme yapılmamıştır. Bu bulgu rehberdeki temel sorunlardan birine işaret etmektedir. Özel ve çeşitli kursların giriş bölümünde kapsamının açıklanmaması ve yanı sıra dershanelerin kapatılmasıyla birlikte bu denetim rehberinin kullanım alanındaki değişikliğin güncellenmemesi rehberin işlevselliğine zarar verebilir.

Yasal belgeye göre eksik ifade edilme $(n=13)$ bir diğer koddur. Rehberde 13 maddede eksik ifadelendirme olduğu belirlenmiştir. Maddelerde gönderme yapılan yasal belgelerdeki açıklamaların ya da diğer bentlerin ilişkili olmasına rağmen rehberde yer almadığı görülmüştür. Bu bulguya örnek verilecek olursa 3.Yönetim Faaliyetleri/Kurumu Açma, Kapatma ve Devir Işlemleri başlığı altında yer alan 2. Madde'de personel arasında iş bölümü yapılması ile ilgili olan Özel Öğretim Kurumları Yönetmeliği Md.32/1-ç bendine gönderme yapılmıştır; ancak diğer bentlerde $(1 / a, b, c, d, e ; 2,3,4)$ de iş bölümü ile ilgili açıklamalar yer almaktadır. Rehberde bu bentler belirtilmemiştir, yasal belgeye göre eksik kalmıştır. Bu noktada eksikliğin nedeni olarak belgeyi hazırlayanların ilgili maddeleri yeterince incelememesi gösterilebilir.

Yasal belgeye göre fazla ifadelendirme $(n=2)$ altında yasal belgelerde yer alan açıklamaların yanı sıra rehberde ilgili bölümde ek olarak yazılan ifadeler ele alınmıştır. Örneğin rehberlik ve denetim ilkeleri arasında MEB Teftiş Kurulu Yönetmeliği'nde yer almayan "bağımsızlık, personelin mesleki yeterliğini geliştirmek, millı̂ birlik ve bütünlügümüzün temel unsurlarından biri olan Türkçenin doğru kullanılması hususunda gerekli duyarlığı göstermek" gibi ek ilkelere yer verildiği belirlenmiştir. Bu durumun hazırlayanların farklı hassasiyet 
noktalarından kaynaklandığı düşünülmektedir. Ayrıca dokümanın kullanım amacı doğrultusunda gerekli görüldüğü hallerde ek açıklamalar yapılmasının rehberin kullanımını olumsuz etkilemeyeceği düşünülmektedir.

Tutarsızlık alt teması altında son olarak ilgili yasal dayanaklara eksik gönderme $(n=26)$ yer almaktadır. Burada rehberdeki maddede yer alması gereken ancak atıf yapılmayan yasal belgeler ele alınmıştır. Rehberin bazı maddeleriyle ilişkili yasal belgeler olmasına rağmen içerikte yer verilmediği görülmüştür. Örneğin Eğitim-Öğretim Faaliyetlerinin Sonuçları başlığı altında Kursiyer / 1. Devam- devamsızlık durumu maddesine MEB özel Kurslar Yönetmeliği Md. 24, 2. Disiplin durumu maddesine Özel Kurslar Yönetmeliği Md. 21, 3. Sosyal etkinliklerin düzenlenme durumu maddesine Özel Öğretim Kurumları Yönetmeliği Md.62/7, 4. Ücretsiz ve burslu kursiyer durumu maddesine Özel Öğretim Kurumları Yönetmeliği Md.62 eklenebilir. Bu durumun rehberi hazırlayanların mevzuata hâkim olmaması ve yeterince araştırma yapılmamış olmasından kaynaklandığı söylenebilir. Bir başka bakış açısıyla da rehberi kullanan kişilerin bu tür ayrıntıları bilecek uzmanlıkta olmasının rehberde ayrıntıya girilmesine gerek duyulmamasına neden olduğu söylenebilir.

Genel bir değerlendirme yapıldığında her ne kadar rehberin giriş kısmında yer alan "Denetim rehberinde yer almayan hususlar için ilgili mevzuat hükümlerine göre rehberlik ve denetim yapılacaktır. Rehberde yer alan mevzuat atıfları bilgi amaçlıdır." ibaresi olsa da tutarsızlık teması altında ele alınan yasal belgenin hatalı ifade edilmesi, yasal belgeye göre güncel olmama, eksik ifade edilme, fazla ifadelendirme, ilgili yasal dayanaklara eksik gönderme kodları rehberin hazırlanma aşamasında gerekli özenin gösterilmediğini düşündürmektedir. Rehberin uygulamaya konulmasında temel amacı Teftiş Kurulu Başkanlığı "...maarif müfettişlerinin görev ve sorumluluklarında uygulama birliğinin sağlanması ve görevlerinin belirli bir standarta göre yapılması..." (MEB, 2014) şeklinde açıklamış ve maarif müfettişleri MEB Rehberlik ve Denetim Başkanlığı ile Maarif Müfettişleri Başkanlıkları Yönetmeliği'nin 70. Maddesinde bu sorumluluk ile görevlendirmiş̧ir. Bu noktada etkili bir denetim için rehberin yasal göndermelerinde hata olmaması, güncelliğini koruması, eksik ifade ya da gönderme yapılmaması beklenmektedir. Rehberin bu noktalarda işlevselliğini yitirdiği söylenebilir.

\section{2. Özel Çeşitli Kurslar Rehberlik ve Denetim Rehberi'nin Alanyazınla ilişkisi}

Araştırmanın bu başlığı altında denetim rehberinin alanyazınla uyumu incelenmiştir. Bu doğrultuda denetim rehberinin alanyazınla tutarlığı ve tutarsızlığı kategorileri oluşturulmuştur. Tutarlıık teması altında uygunluk kodu yer almaktadır. Tutarsızlık kategorisi altında içerik analizi sonucunda içerik eksikliği, atıfsızlık, kavram tutarsızlı̆̆ı, aykırılık kodlarına yer verilmiş̧ir. Analiz sonucunda ulaşılan tema, kategori, kodlar ve frekanslar Tablo 3'te gösterilmektedir.

Tablo 3. Özel Çeşitli Kurslar Rehberlik ve Denetim Rehberi'nin alanyazınla ilişkisinin incelenmesi

\begin{tabular}{|c|c|c|}
\hline Tema & Kategoriler & Kodlar \\
\hline \multirow{5}{*}{ 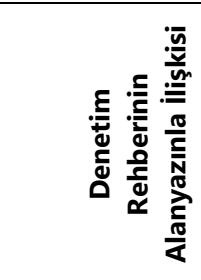 } & $\begin{array}{l}\text { Denetim Rehberinin Alanyazınla } \\
\text { Tutarlılığı }\end{array}$ & Uygunluk \\
\hline & \multirow{4}{*}{$\begin{array}{l}\text { Denetim Rehberinin } \\
\text { Tutarsızlığı }\end{array}$} & İçerik eksikliği \\
\hline & & Atıfsızlık \\
\hline & & Kavram Tutarsızlığı \\
\hline & & Aykırılık \\
\hline
\end{tabular}

\subsection{Denetim Rehberinin Alanyazınla Tutarlılığı}

Denetim rehberinin alanyazınla tutarlıı̆ı kategorisi altında yer alan uygunluk kodu ile rehberin genel olarak denetim alanyazınıla uygunluğu incelenmiştir. Bu noktada rehberin denetim ve rehberlik kavramlarına yönelik olarak içerik anlamında alanyazınla uyumlu olduğu söylenebilir. Örneğin Özel Çeşitli Kurslar Rehberi'nde kurumlarım eğitim-öğretim faaliyetleri, yönetim faaliyetleri, mali iş ve işlemler, izleme ve değerlendirme, yönetici bilgileri, örnek 
uygulamalar ve genel değerlendirme aşamaları yer almaktadır ve rehberde yer alan bu aşamalar denetim alanına özgüdür.

\subsection{Denetim Rehberinin Alanyazınla Tutarsızlığı}

Denetim rehberinin alanyazınla tutarsızı̆̆ı kategorisinin içerik eksikliği kodu alanyazında olmasına rağmen rehberde kullanılmayan kavramlar vb. olduğunda tercih edilmiştir. Bu kodu oluşturan bulgulardan biri rehberlik ve denetim ilkeleri bölümünde hesapverebilirlik ilkesinin yer almamasıdır. Hesapverebilirlik kavramının denetimle yakından ilişkili bir kavramdır. Denetim ilkelerinde yer alan şeffaflık kavramının bütünleyicisi olarak görülen bu kavram kural ve standartlara uyma noktasındaki sorumluluğu ifade etmektedir (Gökçe, 1994, Başar, 2000). Hesapverebilirlik ve şeffaflık temelinde denetim raporlarının ve geribildirimlerinin paydaşlarla paylaşılması denetimin sağlıklı yapılmasını sağlar (Gündüz ve Göker, 2017). Denetim, iyi yapılandırıldığı ve sağlıklı bir geribildirim sistemine oturtulduğunda eğitim sistemi yeni durumlara da hızlı ayak uydurarak gelişim sağlar (Bozkurt ve Karabıyık, 2003). Ayrıca 5018 Sayılı Kamu Mali Yönetimi ve Kontrol Kanununda kamu yönetişiminde hesapverebilirlik ilkesine vurgu yapılmakta ve hesapverebilirlik türleri ayrıntılandırılarak yasal temele dayandırılmaktadır. Bu noktada denetim ilkeleri arasında hesapverebilirlik kavramının yer alması gerektiği düşünülmektedir. Bu eksikliğin rehberi hazırlayanların alanyazın hakimiyetinin yeterli olmamasından kaynaklandığı düşünülmektedir.

Atıfszzlık kodu denetim rehberinin alanyazınla tutarsızlı̆ı kategorisinin bir diğer kodudur. $\mathrm{Bu}$ kod oluşturulurken rehberin bilimsel çalışmalarla desteklenip desteklenmediği üzerinde durulmuştur. Rehberin genelinde alanyazına herhangi bir atıf yapılmamıştır. Bu koda ilişkin rehberin Eğitim-Öğretim Faaliyetlerinin Sonuçları bölümünde Sorunlar ve Çözüm Önerileri başlıkları örnek verilebilir. Bu başlıklar altında "Sorunlar tespit edilirken; mevzuat, üst politika belgeleri (Kalkınma Planı, Hükümet Programı, Millî Eğitim Bakanlığı Stratejik Planı) ile okul/kurumun stratejik planında eğitim ile ilgili ortaya konulmuş amaç ve hedefler göz önünde bulundurulur." ve "gerçekçi ve uygulanabilir önerilere yer verilmelidir" ifadeleri yer almaktadır. Bu bölümde bilimsel çalışmalardan da yararlanılabileceği vurgulanabilir. Etkili bir denetim için bilginin temel alınması önem taşımaktadır (Hoy ve Miskel, 1978). Bu bağlamda eğitbilimcilerin pratiğin teorilerini hazırladıklarında ve bu birikim yasal belgelere yansıtıldığında eğitim bilimliliğinden söz edilebilir (Toprakçı́, 2008; Toprakçı, Dağdeviren, Oflaz ve Türe 2010). Rehberin yasal bir belge olduğu düşünüldüğünde denetimin daha etkili yapılabilmesinin bilimsel çalışmalara dayandırılarak sağlanacağı düşünülmektedir.

Kavram tutarsızlığı kodu rehberde ele alınan bazı kavramların birbirini kapsadığı ya da alanyazında aynı anlamda kullanıldığı durumları ifade etmektedir. Bu kodu oluşturan bulgulardan birisi "denetim" ve "rehberlik" kavramlarının alanyazındaki kullanımlarına yöneliktir. Denetim kavramı içerisinde rehberliği de barındırmaktadır. Bir diğer kavram tutarsızlığı bulgusu da "açıklık" ve "şeffaflık" kavramlarına yöneliktir. Alanyazında saydamlık anlamında kullanılan "şeffafık" ve "açıklık" aynı kavramı karşılamakta, yeniliğe açıklık ise bir başka anlamı ifade etmektedir. Rehberde yer alan bu kavramların kullanım karmaşasının rehberi hazırlayanların alanyazın hâkimiyetinin zayıf olmasından ve bilimsel çalışmalardan yeterince yararlanılmamasından kaynaklandığı düşünülmektedir.

Aykırlık kodu alanyazınla çelişkili bölümlere yönelik oluşturulmuştur. Bu kodu oluşturan bulguya örnek olarak rehberde yer alan denetim aşamaları verilebilir. Rehberde aşamalar bulgulara ulaşma, bulguların paylaşılması ve değerlendirme toplantısı şeklinde ifade edilmektedir. Alanyazında ise denetim aşamaları modellere göre değişiklik göstermektedir. Örneğin kliniksel denetim gözlem öncesi görüşme, gözlem yapma, analiz, gözlem sonrası görüşme ve değerlendirme aşamalarından oluşurken gelişimsel denetimde uygun davranışın seçilmesi, seçilen davranışın uygulanması ve gelişimin sağlanması aşamaları yer almaktadır (Aydın, 2005; Taymaz, 2013). Rehberdeki denetim aşamalarının alanyazın temelinde ele alınmadığı görülmektedir. Bu bağlamda rehber hazırlama sürecinde mevzuat çerçevesinde 
kalındığını, alanyazında etkili denetim için ortaya konulan çalışmalarla çelişkili bir durum olduğu düşünülmektedir.

\section{SONUÇ VE ÖNERILER}

Araştırmanın bu bölümünde elde edilen sonuçlar ile bu bağlamda uygulayıcılara ve araştırmacılara yönelik önerilere yer verilmiştir. Şekil 2'de araştırmanın sonuçları kategoriler ve kodlar bağlamında gösterilmiştir.

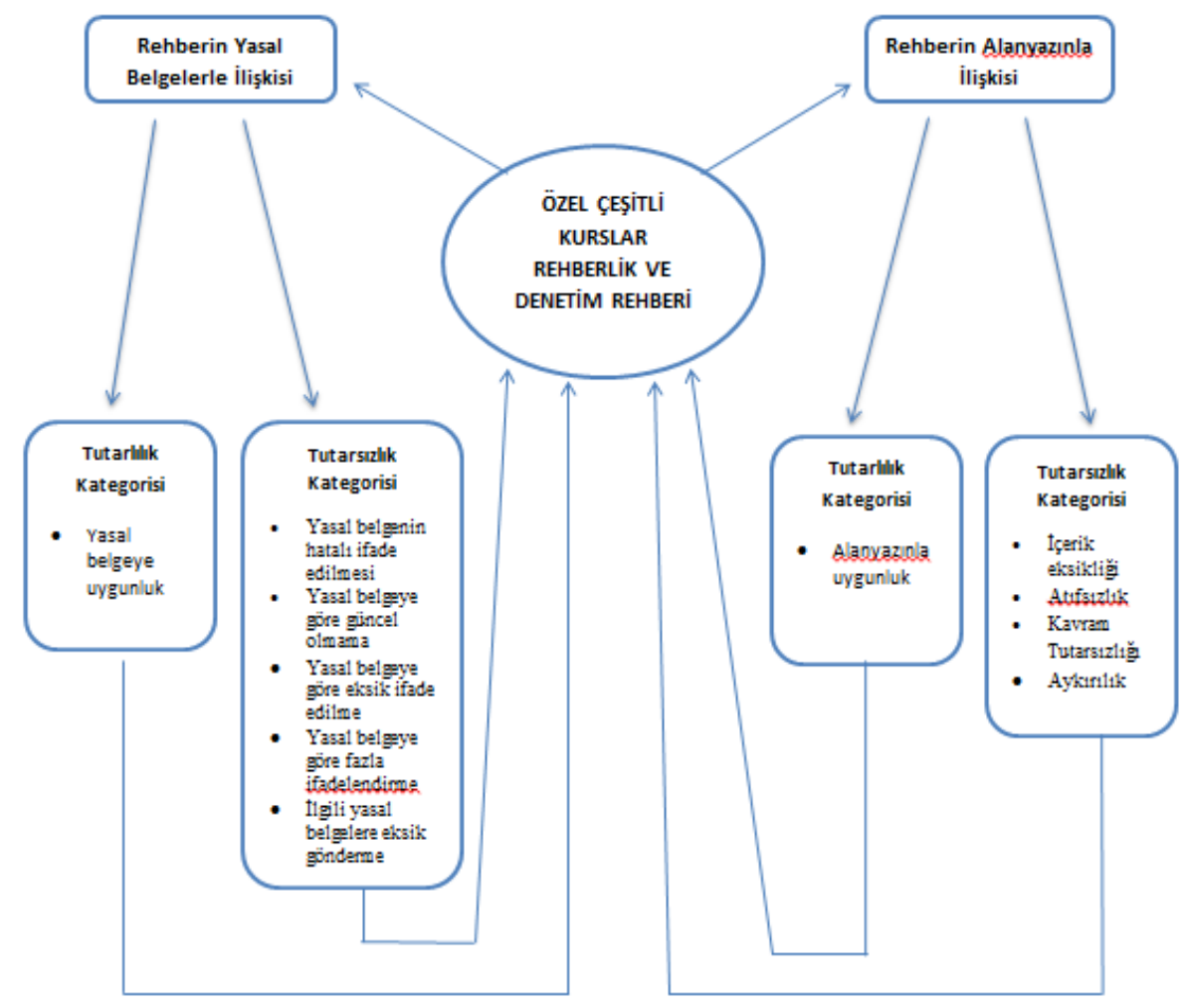

Şekil 2. Araştırma sonuçlarının özeti

Şekil 2'de görüldüğü üzere Özel Çeşitli Kurslar Denetim Rehberi yasal belgeler ve alanyazın temelinde incelenmiştir. Araştırma sonucunda rehberin yasal belgelerle tutarlıı̆ııın, tutarsızlığına göre daha yüksek olduğu sonucuna ulaşılmıştır. Ancak buna karşın kullanıc dostu bir rehber olabilmesi için bu sayının yetersiz olduğu ve tutarsızık gösteren çok sayıda maddenin yer aldığı görülmüştür. Ayrıca tutarlıık gösteren bölümlerin zaman içinde diğer maddelerde olduğu gibi zaman aşımına uğrayabileceği düşünülmektedir.

Tutarsızlık kategorisinde en çok ilgili yasal belgelere eksik gönderme koduna rastlanmıştır. Maddelerle ilişkili yasal belgelerin rehberde yer almamasının rehberi hazırlayanların güncel mevzuata ilişkin bilgi eksikliğinden kaynaklandığı düşünülmektedir. Bu bağlamda müfettişlere rehber hazırlama sürecinde denetim sırasında kullanılabilecek mevzuata ilişkin seminerler verilebilir.

Tutarsızlık kategorisini oluşturan kodlar arasında yasal belgeye eksik ifade edilme, fazla ifadelendirme ve hatalı ifadelendirme kodları yer almaktadır. Bu bulgular rehberde yer alan maddelerin gönderme yapılan yasal belgelerdeki metinlerle tutarsız olduğunu göstermektedir. Rehberi kullanan müfettişlerin kendi alanlarında yetkin olduğu varsayımına dayanılarak maddelerde ayrıntılara yer verilmemiş olabilir. Ancak rehberlerin ortaya çıkış amacı uygulamadaki standardı sağlamak olduğu düşünüldüğünde ve kullanıcıların zaman zaman müfettişlerin yanı sıra okul yöneticilerinin de olabileceği varsayımında hareketle içeriğin 
hazırlanma sürecinde hasas davranılması gerektiği düşünülmektedir Bu bağlamda içerik ile ilgili hangi mevzuatların ve hangi maddelerin hangi kısımlarının rehberde yer alacağı üzerine derin araştırmalar yapılması; bunun için kurullar kurulması ve bu kurullarda eğitim denetiminin yanı sıra hukuk, maliye gibi alan uzmanlarının da yer alması önerilebilir. Ayrıca metinlerin Türkçe yazım ve anlatım kurallarına uygunlu da bir dil uzmanı tarafından da kontrol edilebilir.

Yasal belgeye göre güncel olmama kodu da tutarsızlık kategorinde yer almaktadır. Rehber yasal belgeler temelinde incelendiğinde bazı maddelerin güncel olmadığı sonucuna ulaşılmıştır. Rehberin güncelliğinin sağlanması kullanıcı dostu olmasını da sağlayacaktır. Mevzuatta sık sık değişiklikler yapılması kullanıcıların da takibini zorlaştırmaktadır. Bu nedenle dijital çağın olanaklarından yararlanılması önerilmektedir. Örneğin yasal dayanakların rehberdeki ilgili bölüme çevirim içi linkinin verilmesi, değişimini takip eden bir yazılım oluşturulması ve yasal belgelerdeki değişimi belirli aralıklarla takip eden bir çalışma grubu oluşturulması rehberin güncel tutulmasını sağlayabilir.

Rehberin alanyazınla ilişkisi incelendiğinde içerik eksikliği, atıfızlık, alanyazınla kavram tutarsızlığı ve aykırılık durumlarıyla karşılaşılış̧ır. Bilimsel çalışmaların uygulama ile, uygulamanın bilimsel çalışmalarla ilişkilendirilmesi yapılan çalışmaların ve denetimin niteliğini artıracağı düşünülmektedir. Bilimsel çalışmaların her alanda olduğu gibi özellikle de eğitim denetiminde temel alınması toplumun gelişimine katkı sunacaktır. Ayrıca akademi ile MEB'in iş birliğinin geliştirilmesiyle denetim sisteminin daha etkili bir noktaya taşınacağı düşünülmektedir. Bu etkileşim çift yönlü olarak bilimsel çalışmaların çeşitliliğine de katkı sağlayabilir. Bu bağlamda bilimsel çalışmalardaki sonuç ve öneriler temelinde denetim sürecinde yaşanabilecek sorunlar senaryolaştırılarak örnek olay şeklinde rehberin çözüm önerileri bölümünde değerlendirilebilir. Yurt içi ve yurt dışı alanyazın taranarak rehberle ilgili araştırmalardan oluşan bir bölüm rehbere eklenebilir. Rehber revize edilirken güncel denetim araştırmalarından yararlanılarak rehberde bu araştırmalara atıflarda bulunulabilir. Eğitim yönetimi ve denetimi üzerine çalışan akademisyenler revizyon sürecine dahil edilebilir. Müfettişlerin eğitim yönetimi ve denetimi alanında yüksek lisans yapmaları teşvik edilebilir. Denetim sürecine ilişkin güncel araştırmalar ve konular için alan uzmanı kişilerin hizmet içi eğitim vermeleri sağlanabilir.

Çalışmanın sonuçları bağlamında araştırmacılara da müfettişlerin rehberlerin kullanımında karşılaştıkları sorunlar ve önerileri üzerine çalışmaları, mevzuatın denetim ile ilişkisini incelemeleri, farklı denetim rehberlerini inceleyerek karşılaştırma yapmaları, rehberin hem biçimsel hem de içerik olarak geliştirilmesi için derinlemesine bir araştırma yapmaları, rehberin farklı bölgelerdeki kullanımında karşılaşılan durumları ele almaları, özel ve çeşitli kurslara yönelik çalışmalar yaparak rehberin geliştirilmesine yönelik araştırma yapmaları önerilebilir.

\section{KAYNAKLAR}

Aydın, I.(2003).Eğitim ve öğretimde etik. Ankara:Pegem A Yayınları.

Aydın, İ. (2005). Öğretimde denetim. Ankara: Pegem A Yayıncılık.

Aydın, M. (2014). Çağdaş eğitim denetimi (6. Baskı). Ankara: Gazi Kitabevi.

Akçay Güngör, A. (2020). Özel Öğrenci Etüt Eğitim Merkezi Rehberlik ve Denetim Rehberinin Yasal Belgeler ve Alanyazın Temelinde İncelenmesi. e-Uluslararası Eğitim Araştırmaları Dergisi, 11 (3) , 90-109. Retrieved from http://www.e-ijer.com/tr/pub/issue/58698/820632

Başar, H. (2000). Eğitimde çağdaş denetim yaklaşımları. Eğitim denetçisi. Ankara: Pegem-A Yayıncılık.

Bozak, A.; Seraslan, D.; Çakır, E. (2017). Maarif Müfettişlerinin Denetim Sistemi Hakkında Yapılan Akademik Çalışmalara iliş̧kin Görüşleri. Elementary Education Online, 16(2), 453-468.

Bozkurt, E.; Karabıyık, İ. (2003). Türk milli eğitiminde denetim sistemi sorunları ve çözüm önerileri: Türk milli eğitim teftiş sisteminde yapılanma sorunu. Ankara: Temsen Yayınları.

Bursalıoğlu, Z. (2010). Eğitim Yönetiminde Teori ve Uygulama. Ankara: Pegem A Yayınları, 9.Baskı.

Bursalığlu, Z. (1979). Okul Yönetiminde Yeni Yapı ve Davranış. Ankara: Eğitim Fakültesi Yayınları No:78.

Bülbül, T. (2018). Yönetim ve Eğitim Yönetimi Kuramları. Editörler: Kamile Demir, Kürşad Yılmaz. Ankara: Pegem A Yayınları. 
Creswell, W. J. (2003). Research design: Qualitative, quantitative, and mixed methods approaches. London: SAGE Publications.

Gökçe, F. (1994). Eğitimde denetimin amaç ve ilkeleri. Hacettepe Üniversitesi Eğitim Fakültesi Dergisi, 10(10), 73-78.

Göker, S.; Gündüz, Y. (2017). Eğitim Denetimi Sürecinde Hesap Verebilirlik ve Şeffaflık Uygulamaları. Ondokuz Mayıs Üniversitesi Eğitim Fakültesi Dergisi, 36 (1), 83-93.

Hoy, W.; Miskel, G. C. (1978). Educational Administration, Theory, Research, and Practice, New York: Random House.

Kahraman, H. (2020). Öğretmenevleri, Öğretmenevi ve Akşam Sanat Okulları Rehberlik ve Denetim Rehberinin Yasal Metinler ve Alanyazın Temelinde İncelenmesi. e-Uluslararası Eğitim Araştırmaları Dergisi, 11 (3) , 123-138. Retrieved from http://www.e-ijer.com/tr/pub/issue/58698/836759

Konan, N.; Bozanoğlu, B.; Çetin, R. (2019). Milli Eğitim Bakanlığı Teftiş Politikalarına İlişkin Okul Yöneticileri ve Öğretmen Görüşleri. Eğitimde Nitel Araştırmalar Dergisi, 7 (4) , 1449-1474.

Milli Eğitim Bakanlığı (MEB) (2014). Milli eğitim bakanlığı rehberlik ve denetim başkanlığı ile maarif müfettişleri başkanlıkları yönetmeliği. Resmi Gazete, 24.05.2014 tarih 29009 sayı. https://www.resmigazete.gov.tr/eskiler/2014/05/20140524-18.htm

Milli Eğitim Bakanlığı (MEB) (2017). Milli Eğitim Bakanlığı Teftiş Kurulu Yönetmeliği. Resmi Gazete, 20.08.2017 tarih 30160 sayı. https://www.resmigazete.gov.tr/eskiler/2017/08/20170820-1.htm

Ölmez Ceylan, Ö, Algam, E. (2020). İl/ilçe Milli Eğitim Müdürlükleri Denetim Rehberinin Yasal Belgeler ve Alanyazın Temelinde İncelenmesi. e-Uluslararası Eğitim Araştırmaları Dergisi, 11 (3) , 179-198 . Retrieved from http://www.e-ijer.com/tr/pub/issue/58698/831894

Özdemir, N, Altuntaş, F. (2020). Denetimde Standartlaşma Çabaları: Motorlu Taşıt Sürücüleri Kursu Denetim Rehberi Örneği. e-Uluslararası Eğitim Araştırmaları Dergisi, 11 (3) , 79-89. Retrieved from http://www.e-ijer.com/tr/pub/issue/58698/807767

Özmen, F.; Şahin, Ş. (2010). İlköğretim Müfettişlerinin Soruşturma Görevi Yerine Getirirken Karşılaştıkları Sorunlar. Dicle Üniversitesi Ziya Gökalp Eğitim Fakültesi Dergisi, (15), 92-109.

Taymaz, H. (2013). Eğitim sisteminde teftiş: Kavramlar, ilkeler, yöntemler. Ankara: Pegem Yayıncılık.

Taymaz, H. (2015). Teftiş Ilkeler Kavramlar Yöntemler. Ankara. Pegem Akademi.

Teftiş Kurulu Başkanlığı (TKB). (2020). Bilim ve Sanat Merkezleri Rehberlik ve Denetim Rehberi. http://tkb.meb.gov.tr/www/yayinlarimiz/icerik/13

Tonbul, Y, Ata Çiğdem, F. (2020). Bilsem Denetim Rehberinin Yasal Belgeler ve Alanyazın Temelinde İncelenmesi. e-Uluslararası Eğitim Araştırmaları Dergisi, 11 (3) , 36-62. Retrieved from http://www.e ijer.com/tr/pub/issue/58698/804118

Tonbul, Y, Ödemiş Keleş, N. (2020). Mesleki Eğitim Merkezleri Rehberlik ve Denetim Rehberi" nin Yasal Belgeler ve Alanyazın Temelinde Tutarlıı̆ııın İncelenmesi. e-Uluslararası Eğitim Araştırmaları Dergisi, 11 (3) , 139-153. Retrieved from http://www.e-ijer.com/tr/pub/issue/58698/803653

Toprakçı, E.(2008). Sınıfa Dayalı Yönetim. Ankara: Pegem Yayınları.

Toprakçı, E., Beytekin, O., F., Doğan, M. (2018). Yargıtayın Özel Öğretim Kurumlarına iliş̧kin Verdiği Kararların İncelenmesi. Turkish Studies, 13(19), 1781-1795.

Toprakçı, E., Oflaz, G., Dağdeviren, İ.,Türe, E. (2010). Eğitim Fakültesi Öğretim Elemanlarının Bilim Anlayışları Temelinde Eğitimin Bilimliliği. Bilim ve Ütopya, 45-56.

Toprakçı, E.; Çakırer, I.; Bilbay, A.; Bagcivan, E.; Bayraktutan, I. (2010). Kuram ve uygulamada eğitim denetmenleri meslek etiği. Educational Policy Analysis and Strategic Research, 5(1), 14-23.

Toprakçı, E.; Taş, Ş. (2020). Yargıtay'ın okul müdürlerine ilişkin verdiği kararların incelenmesi. E- Uluslararası Eğitim Araştırmaları Dergisi, 11(1), s.20-40.

Toprakçı, E, Bakır, D. (2020). Yabancı, Azınlık ve Milletlerarası Okullar Denetim Rehberinin Yasal Belgeler ve Alanyazın Temelinde Incelenmesi. e-Uluslararası Eğitim Araştırmaları Dergisi, 11 (3) , 16-35. Retrieved from http://www.e-ijer.com/tr/pub/issue/58698/800326

Toprakçı, E, Özerten, K. (2020). Özel Öğrenci Yurtları Rehberlik ve Denetim Rehberinin Yasal Belgeler ve Alanyazın Temelinde İncelenmesi. e-Uluslararası Eğitim Araştırmaları Dergisi, 11 (3) , 199-216. Retrieved from http://www.e-ijer.com/tr/pub/issue/58698/817509

Yıldırım, A.; Şimşek, H. (2013). Sosyal bilimlerde nitel araştırma yöntemleri. Ankara: Seçkin Yayıncılık. 


\title{
The Investigation of the Various Special Courses Supervisory Guideline Based on Legal Documents and Literature
}

\author{
Phd. Özden Ölmez Ceylan \\ Ministiry of National Education-Türkiye \\ olmezozden@gmail.com
}

\author{
Hüseyin Yaldız \\ Ministiry of National Education-Türkiye \\ huseyinyaldiz@gmail.com
}

\begin{abstract}
The aim of this research is to examine the Various Special Courses Supervisory Guideline published by the Ministry of Education Inspection Board on the basis of legal documents and literature and to develop suggestions. The guide was subjected to document analysis according to the qualitative research method. The data were analyzed by content analysis. As a result of the analysis, it was concluded that the guide is generally consistent with the legal documents. However, the results of lack of content according to the items cited in line with the analysis, not being up-to-date according to legal documents, and excessive and erroneous statements according to the legal basis were found. Although the relationship between the guide and the literature has consistency in general, it has been concluded that there are concepts used inconsistently with the literature, there are no references to scientific studies and that the lack of use of some concepts causes a lack of content and there are uses contrary to the literature. In this context, giving seminars for the preparation of the guide to inspectors, adding online links to the guide to keep it up-to-date and creating software to keep it up-to-date, and adding the results of the research in the literature to the guide are some of the suggestions.
\end{abstract}

Keywords: Educational supervision, supervisory guide, special and various courses 


\section{EXTENDED ABSTRACT}

Problem: The supervision system is important in terms of increasing the quality of institutions and contributing to the development of society. In other words, it is a mechanism that supports an institution concerning quality and quantity to develop in line with the targets. For this reason, supervision is of vital importance in terms of taking necessary measures for problematic areas and increasing efficiency (Taymaz, 2015). Understanding to what extent organizations can reach their goals and their efficiency can be achieved by evaluating the input, processing process and outputs in a planned and continuous manner (Aydın, 2014). The healthy execution of this process explains the role of supervision in its process of becoming social benefit. The purpose of the supervision can be expressed as determining the required standards and revealing the compatibility with the existing situation (Toprakçı \& Taş, 2020). It is also important that the supervision can be carried out effectively in line with this purpose.

The Ministry of National Education Inspection Board prepared Guidance and Inspection guides to implement an effective supervision system (MEB, 2014). The guide for the Various Special Courses discussed in the study is one of them. In the introduction part of the guide, as in the other guides, the purpose, scope, basis and definitions are included. Then, supervision principles, planning and execution stages of the supervision process, and reporting standards are included. In the articles, references are made to the legal documents to which the explanations are related. At this point, the expectation arises that the legal documents associated with the articles in the guide will guide the person who will conduct the supervision in an accurate, detailed and up-to-date manner. Considering that the functioning of educational institutions is based on legal principles (Toprakçı, Beytekin, \& Doğan, 2018), the consistency of the guide with the legal documents referred to is also important. In addition to being consistent with legal documents, it is considered that it is important to base the guidelines on a scientific basis. Toprakci et al. (2010), on the other hand, emphasized that educational science can only be mentioned when educational practice is based on theory and the synthesis of theory and practice reflected in legal documents. At this point, the association of guides with the literature can be considered among the features that the guide should have. However, no research has been found on the quality and supervision of Various Special Courses. In this research, it was aimed to examine the Special Various Courses Guidance and Inspection Guide on the basis of legal documents and literature. In this context, it is expected that the research will contribute to the supervision literature and will shed light on the future applications and researches with the positive and negative points determined in the research.

Method: In the research, the document analysis technique was used based on the qualitative research method. In 2016, The Ministry of National Education Inspection Board published 16 guides prepared for the supervision of various institutions. The study document is the Various Special Courses Supervisory Guide, which is among the published guides. The guide as a public document has been seen appropriate for document review and has been analyzed according to the phases of document review. Themes, categories and codes were created through content analysis. The first theme discusses the relationship of the supervision guide with legal documents. In this theme, the consistency between the explanations in the guide and the laws, regulations, directives, circulars and other documents are examined. As the second theme, the relationship of the supervision guide with the literary documents is discussed. The consistency of the guide with the literature was examined. In order to ensure the validity of the study, colleague confirmation was made first. For this purpose, researchers who examined the guides of the Ministry of National Education Inspection Board for different institutions met regularly. Meetings were held on the internet every week on the specified day and time via live meeting 
tools and these meetings were recorded so that they can be watched again. In these meetings, discussions were held on primarily how the guides could be examined. Disagreements were discussed and meetings continued until consensus was reached. In order to get expert opinion, a competent academic who has publications in the field of supervision and an education inspector participated in these meetings. These experts provided feedback during the meetings. In order to ensure validity and reliability, attention has been paid to analyzing the evaluated guidelines based on consensus and making detailed explanations. In addition, in order to increase external reliability, the raw data of the research were kept in order to be shared on request or to be compared in another study.

Findings: As a result of the analysis, it was concluded that the guide is generally consistent with the legal documents. However, it was determined that there is a lack of content according to the legal articles referred to in line with the analysis. It was concluded that some of the legal documents referred to in the guide are not up to date. It was observed that there were excessive and erroneous statements according to the legal basis. As for the relationship between the guide and the literature, it is seen that the guide is generally consistent. Nevertheless, it has been concluded that there are concepts used inconsistently with the literature. It has been determined that there is no reference to scientific studies. In addition, it has been observed that some concepts in the literature were not used and this situation caused a lack of content. In addition to all these, it was concluded that there were contradictory expressions with the literature.

Suggestions: Seminars for the preparation of the guide can be given to supervisors. Online links can be added to the guide to keep it up-to-date. A special software can be written for the guide to keep it up-to-date. Scientific research results can be added to the guide scripted specifically to the experienced problems. Supervisors may be encouraged to obtain a master's degree in educational management and supervision. Researchers may be advised to make comparisons with international practices. By examining the supervision reports, it can be examined whether the guide has achieved its purpose. By making interviews with the inspectors who use the guide, their experiences during the process of supervision can be a research subject. 